УДК 091 : 316.64

Гоян І. М., Сторожсук С. В., Федик О. В.

doi: 10.32620/gch.2018.3.01

\title{
СОЦІАЛЬНА ПРОГРАМА РЕНЕСАНСНОГО ГУМАНІЗМУ
}

У статті показано, щзо започаткована ренесансним гуманізмом соиіальна програма закладає підвалини для формування нового образу людини, поміж тим вона не призводить до формування автономного соціального суб'єкта й особистості в сучасному ї̈ розумінні. Це зумовлено відсутністю концептуальних $і$ соиіокультурних підвалин для усвідомлення природної рівності й унікальності всіх людей, унаслідок чого людина й надалі залишається залежною від наперед визначених сочіальних чинників. Як наслідок, вимога постійної активності, започаткована ренесансним гуманізмом, поєднується з відсутністю конструктивної програми індивідуального й суспільного розвитку, щзо зумовлює істотну дезорієнтацію людини у світі.

Ключові слова: людина, соціальна програма, соціокультурні зміни, ренесансний гуманізм, особистість, антропоцентризм.

The article shows that the social program, initiated by Renaissance humanism, has been laying the foundations for the formation of a person's new image, meanwhile, it does not lead to the formation of an autonomous social subject and personality in his/her contemporary understanding. This is stipulated by the lack of conceptual and socio-cultural foundations for realizing the natural equality and uniqueness of all people, as a result the person remains dependent on predetermined social factors. Consequently, the requirement of constant activity, initiated by Renaissance humanism, is combined with the absence of a constructive program of individual and social development, which causes a significant disorientation of man in the world.

Keywords: man, social program, socio-cultural changes, Renaissance humanism, personality, anthropocentrism.

В статье показано, что сформированная в рамках ренессансного гуманизма сочиальная программа закладывает основу для формирования нового образа человека, между тем она не приводит к формированию автономного сочиального субъекта $u$ личности в современном ее понимании. Это обусловлено отсутствием концептуальных $и$ соииокультурных оснований для осознания естественного равенства и уникальности всех людей, в результате чего человек продолжает оставаться зависимым от заранее определенных сочиальных факторов. Как следствие, требование постоянной активности, выдвинутое ренессансным гуманизмом, сочетается с отсутствием конструктивной программы индивидуального и общественного развития, что приводит к существенной дезориентации человека в мире.

Ключевые слова: человек, сочиальная программа, сочиокультурные изменения, ренессансный гуманизм, личность, антропоцентризм.

Постановка проблеми. Докорінні соціокультурні трансформації, що відбуваються у всьому світі, призвели до знецінення тих соціальних стандартів, які забезпечували добробут індустріального суспільства, зумовивши постання нової 
соціальної програми. Остання має стати концептуальним підгрунтям сучасних педагогічних стратегій, адже саме на них покладається головна відповідальність за забезпечення людини необхідними в нових соціокультурних умовах знаннями й компетенціями. Поміж тим у сучасному українському суспільстві реформування педагогічних стратегій, так само як і соціокультурні трансформації, сприймаються надзвичайно неоднозначно. Вагома частина суспільства, як свідчать ЗМІ, дуже занепокоєна новаціями, які відбуваються у сфері освіти, убачаючи в них загрозу зниження рівня освіти, яке 3 необхідністю призведе до зростання соціальної нерівності й, відповідно, несправедливості й дискримінації.

Усвідомлення незворотності тих змін, які відбуваються в сучасному соціумі, а 3 ним і зростання рівня толерантності до змін можливі тільки в тому випадку, коли в суспільній свідомості з'явиться чітке усвідомлення історичного характеру тих концептів і соціальних програм, які визначають життя кожної конкретної людини й суспільства в цілому. Інакше кажучи, для того щоб ми могли зрозуміти якість $\mathrm{i}$ напрям тих реформ, які відбуваються в сучасній Україні та світі загалом, ми повинні усвідомити витоки й мету тих педагогічних і світоглядних стратегій, якими ми користуємось у власному житті. Це, своєю чергою, актуалізує переосмислення тих соціальних програм, які визначали життя суспільства в різні історичні періоди. Далеко не останнє місце в контексті такого дослідження належить соціальній програмі епохи Відродження, адже, з одного боку, саме $з$ цього часу дослідники зазвичай виводять витоки сучасності, а з другого боку, ця епоха, так само як і наша сучасність, позначена істотними соціокультурними й світоглядними трансформаціями, а тому осмислення тих процесів, які започаткував Ренесанс, може сприяти більш глибокому усвідомленню змін сьогодення.

Ступінь наукової розробки проблеми. Слід зазначити, що осмислення базових ідей ренесансного гуманізму вже неодноразово ставало предметом наукових розвідок різних дослідників, які намагалися сформувати загальний образ i прагнення мислителів цієї доби. У цьому контексті доречно згадати роботи С. Авєринцева [1], Л. Баткіна [3, 4], П. Біциллі [5], О. Горфункеля [8], І. Гояна [19], М. Гуковського [9], М. Дойчика [11], Е. Кассірера [12], О. Лосєва [14], С. Сторожук [21], Й. Гейзинги [20], О. Федик [19] та ін. дослідників, які в теоретико-методологічному плані збагатили сучасне бачення здобутків цього історико-філософського періоду.

Надзвичайно пильна, здавалося б, увага українських і зарубіжних дослідників до інтелектуальних здобутків доби Відродження супроводжується відсутністю праць, де розкривається своєрідність започаткованої гуманістами соціальної програми. Поміж тим, на наш погляд, саме остання надає можливість зрозуміти роль, місце й призначення людини у світі. 3 другого боку, такий підхід надає можливість усвідомити цінність цієї програми з перспективи сьогодення.

3 огляду на сказане, мета нашого дослідження полягає в розкритті світоглядних i соціокультурних передумов формування соціальної програми епохи Відродження й розкритті своєрідності породженого нею образу людини.

Основна частина. Своєрідність та інтенції соціальної програми, сформованої ренесансним гуманізмом, важко зрозуміти, не усвідомлюючи тих соціокультурних 
змін, що розпочалися в цей час. Адже, хочемо ми того чи ні, мусимо визнати, що головною передумовою виникнення гуманізму було те, що в XIII-XIV ст. містадержави Північної Італії стають центрами міжнародної торгівлі, завдяки чому Флоренція, Мілан, Венеція, Болонья та інші міста перетворилися на великі й заможні економічні центри [13]. У міському виробництві в цей час дрібні ремісничі осередки починають перетворюватися на великі підприємства, що мають уже не цеховий, а ранньомануфактурний характер, а тому потребують великої кількості робочих рук як кваліфікованих фахівців, так і майже некваліфікованих робітників чорної праці. Число останніх у передових містах Італії стає настільки значним, що вони перетворюються на велику й досить грізну соціальну й політичну силу насамперед для тих підприємливих городян, які вже до початку XIV ст. витіснили феодалів 3 активного політичного життя, із землеволодіння, торгівлі, банківсько-лихварської справи, ремісничого виробництва тощо й наполегливо прагнули монополізувати провідні позиції у всіх цих сферах у своїх руках. Зростання економічної й політичної ролі міст і міського населення зумовило поступові зміни й у сільському господарстві - кріпосна залежність селян починає змінюватися різними формами оренди, найчастіше з частки врожаю [9, с. 330].

Економічні й політичні зміни, які розпочалися в тогочасній Італії, були досить істотними, а тому потребували осмислення, оскільки зазвичай входили в суперечність iз соціальними, етичними й політичними тощо нормами, які продукувала тогочасна католицька церква. Унаслідок цього в середовищі італійських інтелектуалів виникало непереборне відчуття, що Священна Римська імперія на чолі з папою римським не здатна забезпечити стабільний розвиток суспільства ні в економічній, ні в політичній, ні в культурній сферах, оскільки вона керується «застарілими» світоглядними нормами. Зокрема середньовічне християнство від початку свого зародження спонукало до пригнічення всього земного, що яскраво проявилося й у світоглядному, і в соціокультурному вимірі в протиставленні «граду земного» й «граду Божого». Між тим, збагачення італійських міст і зміна у формах матеріального виробництва формували підвалини для розвитку держави й культури, які поступово набували секулярного характеру [13].

Нові світоглядні інтенції зародилися під впливом поступової зміни соціальної структури суспільства, яка, своєю чергою, сприяла появі великої кількості надзвичайно заможних людей (як, наприклад, компанії Барді й Перуцці), які фінансували навіть провідні тогочасні держави, завдяки чому отримали можливість визначати внутрішню й зовнішню політику. У середовищі цього «новонародженого третього стану» поступово почав проявився живий інтерес до спадщини Античності. 3 одного боку, він був викликаний великою кількістю археологічних пам'яток, що збереглися на півострові, однак, з другого боку, це зумовлювалося гострим відчуттям внутрішньої суперечливості, яке визначала цілком логічна опозиція до християнської аксіології. Адже, як справедливо зауважує Д. Лалетін, першим, що впадало у вічі «нової інтелігенції» навіть за позірного зіставлення пам'яток Античності й норм Середньовіччя, були відмінності в розумінні людини й значення іiі земного життя. Так, на відміну від середньовічного світогляду, у межах якого панувало зневажливе 
ставлення до людського тіла, яке розглядалося як причина людської гріховності, антична культура, як зауважував О. Лосєв, була наскільки тілесною, матеріальною твори мистецтва й передусім скульптура відображала вродливих, гармонійно розвинених у фізичному плані людей $[13,14]$. Відповідно, поступове знецінення християнської догматики й аксіології породжувало припущення, що духовно прекрасне не може бути фізично потворним, а тому Христос, який у цей час залишався ідеалом, починає розглядатися не тільки як духовно прекрасна людина, а й гармонійно розвинена фізично. Цю ідею прекрасно демонструє ренесансне мистецтво, де Христос зображується у вигляді такого собі античного атлета, як це представлено у творах Рафаеля чи Леонардо да Вінчі. Таким чином, зауважує О. Лосєв, людина епохи Відродження з необхідністю «мислиться фізично, тілесно, об’ємно і тривимірно», формуючи підвалини до утвердження нового образу людини [14].

За твердженням М. Гуровського, саме в цей бурхливий і повний соціокультурних та світоглядних потрясінь період і зародився новий тип людини - господаря життя. Висновок дослідника цілком правомірний, адже тогочасний італійський городянин починає підійматися над становими привілеями завдяки своїй енергійності й заможності, унаслідок чого особливо пишається власним становищем. «Нова людина» стає невгамовною у своїй жадобі до збагачення, а тому не тільки не бажає пригнічувати свої пристрасті на догоду морально збанкрутілому в той час католицькому духовенству, а й виставляє навіть найгірші свої риси напоказ - вона пишається своєю індивідуальністю. Образ нової людини починає панувати в літературних творах, де все більше й більше уваги приділяється благам земного життя, земним радощам і досягненням [9, с. 330].

Чільна увага до земного життя та його благ, на думку багатьох дослідників, серед яких передусім хотілося б згадати Г. Гегеля, В. Віндельбанда, Б. Рассела та Й. Гейзинга та ін., не дає підстав вважати, що в цей час відбувся докорінний розрив із попередньою світоглядною традицією й передусім християнським світоглядом. Так, приміром, на думку Й. Гейзинги, немає підстав недооцінювати християнський характер Відродження й переоцінювати значення античного впливу [20, с. 472]. Водночас із цим дослідник акцентує увагу на перебільшеній оцінці ренесансного індивідуалізму й оптимізму. Такий висновок ученого, на наш погляд, цілком правомірний, адже, як відомо, поряд із блискучими досягненнями в культурі, передусім художній, епоха Відродження характеризується низкою страшних потрясінь. У цьому контексті можна згадати не тільки вкрай жорстокі релігійні війни, а й неодноразові епідемії, у підсумку яких кількість населення в тогочасній Свропі зменшилася чи не на третину. Між тим чи не найстрашнішим феноменом цього часу стала інквізиція, вироки якої неодноразово були вкрай корумпованими. У підсумку сумлінної й невпинної роботи інквізиції знищувалися не тільки кращі представники простого населення, а й кращі тогочасні уми, серед яких провідне місце, безумовно, має Дж. Бруно. Третім феноменом i, що важливо в цьому контексті, не завжди позитивним елементом культури епохи Відродження став розвиток окультизму, практики якого часто супроводжувалися вкрай жорстокими ритуалами та сприяли 
зростанню невігластва населення. Усе це, у єдності 3 початком тогочасної економічної кризи, за твердженням Д. Лалетіна, дає підстави спростувати однозначно позитивну оцінку епохи Відродження в історії європейської культури [13]. Не варто забувати й того, що саме в період Відродження відбувається небувалий спалах корупції (передусім у церковних колах), який сприяв утвердженню антиклерикалізму в тогочасному інтелектуальному дискурсі.

Амбівалентність, яка проявилася в соціокультурному бутті людини епохи Відродження, забезпечивши іiі тісний спадкоємний світоглядний зв'язок як із епохою Середньовіччя, так і епохою Нового часу, зумовлює ту неоднозначну оцінку, яка зустрічається в інтелектуальному дискурсі. Приміром, Б. Рассел вважає, що «епоха Відродження не була періодом великих досягнень у сфері філософіï, але вона дала відомі плоди, які стали необхідною передумовою величі XVII століття» [18]. Не вбачав особливої величі у світогляді цієї доби й Г. Гегель, а тому в «Лекціях з історії філософії» розглядав епоху Відродження як завершальний етап розвитку середньовічної думки. На його погляд, у мислителів епохи Відродження ми можемо побачити «устремління проникнути в справжнє й велике», між тим «вони все ж безглуздим чином, безглуздо кружляли як у галузі своїх душевних переживань, так і в зовнішніх обставинах свого життя. Ми, таким чином, знаходимо в них велику оригінальність, суб'єктивну духовну енергію, але в той же час зміст у них надзвичайно різноманітний і нерівноцінний, а в їх розумі панує велика плутанина» [7]. Роздуми тогочасних мислителів, продовжує свою думку Г.Гегель, «демонструють нам лише занепокоєння їх характеру, розлад, обурення й внутрішні переживання зумовлені навколишніми умовами життя й прагненням звільнитися від цього душевного стану, досягти стійкості. Ці чудові явища мають схожість із землетрусом, коли вулкан починає викидати з себе лаву; цей вулкан, що утворився в глибинах, і створює нові творіння, які, однак, поки що ще дикі й невпорядковані [7].

Загалом погоджуючись 3 оцінкою ренесансного мислення Г. Гегелем, усе ж вважаємо іiі важливим і окремим, хоча й перехідним, етапом у становленні філософської думки. Адже, як справедливо зауважував О. Горфункель, «долі філософських учень, як i долі самих філософів, ми не можемо зрозуміти поза соціально-політичними та ідеологічним конфліктами епохи», оскільки філософська думка мислителів Ренесансу була нерозривно пов'язана зі своєрідністю тогочасного соціокультурного буття, зокрема боротьбою італійських городян за демократизацію тогочасних міст-держав проти абсолютизму, у тому числі й католицької церкви [8, с.7]. Окрім того, важливе значення для розвитку тогочасного інтелектуального дискурсу мали Великі географічні відкриття, які зумовили руйнування європоцентризму та сформували підвалини для спростування панівної в цей час системи Всесвіту Арістотеля-Птолемея.

Зміни, що розпочалися в усіх сферах соціокультурного буття, формували підвалини для спростування середньовічної антропології з притаманною їй вірою, що тілесна природа людини від самого початку гріховна й не може бути виправлена в принципі, як би людина не прагнула це зробити в очах Бога. У цьому їй не допоможуть навіть добрі справи, адже вони не мають жодного значення для 
божественного абсолюту, що існує поза межами добра i зла - чисто людськими, а значить неправильними, поняттями. Сдиними чеснотами людини в такому випадку стають тільки терпіння в стражданнях і надія на спасіння.

На зміну запропонованого епохою Середньовіччя приниження земного життя й благ людини в епоху Відродження приходить нова парадигма антропоцентризму. У цей час починає домінувати думка, що справді християнським ставленням до людини $\epsilon$ не покаяння в гріхах, а навпаки, прощення, до чого й закликав Христос. Крім того, поступово утверджується погляд, що Богові мало сенсу карати людину за те, що Він сам же в ній створив за «образом Своїм». Більше за те, як показував життєвий досвід, розум допомагає в житті, а це означає, що Бог на боці розумних (а точніше мудрих, як сказано в Книзі Премудрості Соломона), а це, своєю чергою, означає, що саме вони більшою мірою відповідають «образу й подобі Бога».

Власне, саме таким чином антропоцентризм приходить до іманентного зв'язку з гуманізмом, який виявляється у формуванні нового розуміння відношення людини й Бога. Зокрема вважається, що людина, будучи створена за «образом і подобою» Бога, має ті ж властивості, як і сам Бог, на чому акцентував увагу ще Діонісій Ареопагіт у праці «Про божественні імена» [2]. Це, своєю чергою, відкрило можливість Дж. Піко делла Мірандола запропонувати власну інтерпретацію акту божественного творення людини: «Не даємо ми тобі, Адаме, ні певного місця, ні власного образу, ні особливого обов'язку, щоб і місце, і образ, і обов'язок ти мав за власним бажанням, згідно з твоєю волею й твоїм рішенням. Образ інших творінь визначений у межах установлених нами законів. Ти ж, не стиснутий ніякими межами, визначиш свій образ за своїм рішенням... Я ставлю тебе в центрі світу, щоб звідти тобі було зручніше оглядати все, що є у світі. Я не зробив тебе ні небесним, ні земним, ні смертним, ні безсмертним, щоб ти сам, вільний і славний майстер, сформував себе... Ти можеш переродитися в нижчі, нерозумні істоти, але можеш переродитися за велінням своєї душі і в вищі божественні... “Той, хто відступить від божественного закону, стане твариною й цілком заслужено”» [0].

Запропонований уривок із праці Дж. Піко делла Мірандола «Промова про гідність людини» [16] надзвичайно красномовно формує своєрідність нового тлумачення людини. Адже, не розриваючи цілком із християнською риторикою, епоха Відродження пропонує власне розуміння «образ і подоба» людини Богу, яке тепер диференціюється за ступенем аксіологічної важливості. Здатність до творення, створення нового стає головним даром, яким наділяє Господь людину. У наслідок висліді цього в період раннього Відродження активність людини у світі рішуче протиставляється спогляданню. Енергійна участь у громадському й соціальному житті, де саме духовна культура 3 притаманними мовними засобами служить способом заохочення людей, розглядалася як поведінка, гідна людини, оскільки надає можливість повноцінно розкрити ії дари [6, с. 16].

Загалом людина епохи Відродження відчуває в собі якісь украй необмежені потенції, що, на iï ж думку, відкривають можливість піднятися їй до рівня божественного, яке вона здатна й повинна осягнути раціонально. Незважаючи на цей цілком оптимістичний пафос і прагнення тогочасної людини зрозуміти й пізнати як 
глибини людських переживань, так і красу природи, усе ж у цей час вона продовжує відчувати своєрідну безпорадність як у ¥іi перетворенні, так i в релігійному осмисленні. Ця безпорадність проявляється в тому, що людина, виявляючи закладені в ній безмежні потенції, часто проявляє не кращі боки. У цьому контексті привертає увагу не тільки вже згаданий нами спалах тогочасної корупції, а передусім деморалізація католицької церкви. Найбільш показовим уособленням цього негативного боку стає папа Олександр IV (Борджіа), дії та непорушна святість якого підтверджувалася формально «Диктатом папи» (1075 р.) [10], але який у буденній свідомості поставав радше «дияволом», аніж святим.

Поступова руйнація світоглядних підвалин середньовічної людини, яка перебувала не тільки в чітко визначеному світі, а й мала наперед визначену долю, призвела до того, що людина епохи Відродження була змушена жити у світі безкінечних творчих поривів, зумовлених широкою свободою, коли, як справедливо зауважує Ф. Петрарка, людина «вже майже все випробувала», між тим не отримавши спокою. Це зумовлено тим, що надії та сподівання людини змінюються з часом, унаслідок чого вона перебуває в постійному стані вагань [0, с. 6]. Подібний внутрішній розлад спостерігається й у «Листах про справи повсякденні», де мислитель акцентує увагу, що доля неначе грається з людиною, обіцяючи їй великі нагороди, між тим насправді часто дарує розчарування, ліками від яких може бути тільки терпіння й невпинна праця [15, с. 39].

Можливість проявити свою свободу та врівноважити життя, за Ф. Петраркою, людина отримує завдячуючи праці, яка $є$ іманентною властивістю людини. «Праця просвітлює; для чоловіка [людини - уточ. наше] немає нічого природнішого, ніж праця, людина народжена для неї, так само як птах для польоту й риба для плавання...», натомість томна бездіяльність дозволена тим, від кого не варто очікувати славного подвижництва [15, с. 42]. У цьому контексті мислитель у дусі протестантизму виступає проти здеморалізованого католицького духовенства, яке поступово втрачає легітимність в очах найосвіченіших тогочасних прошарків, а відтак не може вважатися посередником людини на шляху до вічного блаженства. Останнє перетворюється на особистий здобуток кожної конкретної людини.

Слід зазначити, що сформоване в епоху Ренесансу уявлення про людину-творця було не просто світоглядною інтенцією, а практичним закликом. У цей час людина аж ніяк не могла не прагнути до творчості, яка піднесе їі до рівня Боголюдини, оскільки в протилежному випадку іiі існування вже не відповідало б новим світоглядним цінностям. Відповідно ж до цих нових цінностей людина-творець (інтелектуал) стала розглядати себе як істоту вільну, творчу, активну, діяльну й індивідуальну. Вона вирізняється посеред інших визнанням власної самоцінності й має абсолютне право на саморозвиток і самореалізацію в процесі своєї життєдіяльності. Суспільство й соціальні інститути посіли другорядне місце й розглядалися лише як умови розвитку творчого потенціалу людини. Цілком закономірно, що така людина навіть моральні підстави стала шукати не в трансцендентній сфері, а в самій собі. У зв'язку з цим О. Лосєв зауважує: «Люди робили надзвичайно дикі злочини і ні в якій мірі в них не каялися, і нехай вони роблять так тому, що останнім критерієм для людської 
поведінки вважалася тоді сама ж морально ізольовано особистість» [14]. По суті справи, ціннісні настанови Ренесансу перетворювали людину в абсолют, який має підстави свого існування в самому собі, він нічим не був обмежений у своїй діяльності й набував повного права використовувати весь навколишній Універсум у власних інтересах.

Обгрунтовуючи важливість земного життя, цінностей і благ людини, гуманісти зазвичай прямо не заперечують християнське вчення про гріхопадіння. Між тим, як справедливо зауважує О. Горфункель, частіше за все вони поводять себе так, ніби про нього забули, а тому у своїх теоретичних побудовах не беруть його до уваги. На їх думку, якщо розглядати людину як нерозривну природну єдність тіла й душі або матеріального й духовного начал, то, відповідно, здійснення нею свого призначення вимагає не боротьби з власною природою, а навпаки, - слідування природі, тобто нерозривній єдності душі та тіла. Таким чином, місце середньовічного конфлікту займають пошуки згоди й гармонії. Це стосується як природи самої людини, так і становища людини у світі природи та суспільстві [8, с. 41].

Попри антропоцентризм і чільну увагу ренесансного дискурсу до проблеми людини, усе ж, на думку Л. Баткіна, у цей час людина не доростає до повноцінної особистості, бо «одиничне ще не дотягнуло до особливого, адже люди цього часу відрізняються один від одного подібного до того, як відрізняються між собою рослини й тварини. Природна унікальність кожної людини ще не містить в собі абсолютної свободи вибору чи внутрішнього обгрунтування, а відтак i не знає поняття особистості» [0, с. 135]. Інакше кажучи, на думку Л. Баткіна, в епоху Ренесансу сформувалися передумови для формування особистості - людина, будучи наділеною від природи певними рисами й творчими потенціями, ще має самостійно віднайти своє власне місце у світі. Між іншим, сам цей пошук ще не призводить до формування особистості.

На перший погляд, висновки дослідника можуть здатися дещо суперечливими, оскільки реабілітація земного життя й земних благ у єдності зі свободою волі визнавала за людиною право самостійно обирати свій шлях. Так, на відміну від премодерної епохи, коли людина могла вважатися особистістю тільки в соціальнопсихологічному контексті, тобто вона була особистістю лише як носій соціального досвіду, який сприймала несвідомо й некритично, в епоху Відродження людина бере на себе відповідальність не тільки за власне життя, а й намагається піднестися над традицією, вона свідомо конструює себе та свій «життєвий світ», не руйнуючи між тим ідеали. Іншими словами, головною підставою для визначення людини епохи Відродження особистістю є те, що вона відроджує в собі цілісність тілесного й духовного, позбавляючись водночас наперед заданих соціальних ролей. Між тим, у горизонті особистості, як справедливо зауважує Л. Баткін, «індивід завжди “не як всі” i - у деяких межах - унікальний незалежно від ступеня особистої яскравості, від свого масштабу, значного або скромного» [3, с. 8].

Виходячи зі зробленого дослідником зауваження, цілком логічно виникає питання, наскільки автономним був сформований епохою Відродження «титан» від вкоріненості в соціальні групи й соціальні стереотипи. Адже утвердження ідеалу 
«універсальної» людини, яка самостійно обирає власний шлях у житті, із позиції нашого часу має з очевидністю породжувати думку про незалежність людини від наперед визначених об'єктивними обставинами факторів людської ідентичності. У цьому процесі людина керується тільки власним критичним розумом і сама визначає, ким вона є й ким вона хоче стати, нівелюючи при цьому всі зовнішні й незалежні від неї чинники. Між тим в епоху Відродження навіть у середовищі гуманістів такого усвідомлення не відбулося. Адже, як справедливо зауважує Л. Баткін, «ренесансній культурі, як і середньовічному християнству, не могла бути відома суто буржуазна ідея демократії, тобто повної рівності всіх людей як громадян, незважаючи на будьякі інші індивідуальні та соціальні відмінності між ними» [4, с. 90]. Навпаки, гуманісти, говорячи про гідність і благородство людини, ніколи не вважали плебеїв гідними й не вихваляли їх, як це, наприклад, зробить Ж. Ж. Руссо в роботі «Еміль». У ренесансній Італії «благородство» хоча й повністю перетлумачувалося, у підсумку чого обраність залишалася цінністю, однак не в сакральному й не у феодальному розумінні. Адже, як уже неодноразово зауважувалося, найбільш гідною для людини $\epsilon$ iї здатність виділятися серед інших. Між тим ця здатність формується не довільно, а завдяки вченості, яка й забезпечує процвітання у всіх справах [3, с. 90].

За твердженням Л. Баткіна, гуманісти започаткували «інтелектуальний i літературний аристократизм», у межах якого цілком логічним видавався вислів Дж. Піко делла Мірандоли: «Хто не філософ - той і не людина». Дійсно, у цей час людьми зазвичай вважалися ті, хто мав благородство (елітарність), яке почало розглядалося як похідне від оволодіння «словесністю» і «вченістю» та, що найголовніше, культурою. Саме вона була предметом особливої гордості гуманістів, оскільки, зберігаючись у пам'яті людей, слугувала головним засобом забезпечення безсмертя [3, с. 90]. Адже, як стверджує Дж. Понтано, ми «відрізняємося від інших живих істот i значно перевершуємо їх тільки двома речами - розумом і мовою. Мова свідчить про те, що ми думаємо або відчуваємо. А тому потрібно всіляко прагнути до того, щоб мова наша доводила б, що в нашій душі й думках немає нічого брудного, тупого, навіженого, немає ніякої заздрості, зарозумілості, легковажності, пристрастей, похоті, жорстокості; навпаки, у серйозних справах у мові має бути гідність, у жартах чарівність і тонкість, у важких обставинах - обачність, на суді - істина і строгість, в горі або нещасті - мужність, у радості й удачі - м’якість, доброта, гуманність. Слова повинні відповідати обставинам і супроводжуватися відповідними й гідними виразом обличчя й жестами» [17, с. 306]. Інакше кажучи, аристократизм гуманістів мав виражати зовнішню значимість, однак завдяки розуму ніколи не переходити в станову зарозумілість.

Загалом варто визнати правомірність думки Л. Баткіна, що гуманісти, обстоюючи привілейоване місце людини у світі та їі право на власне самовираження, тільки підійшли до формулювання концепту особистості, оскільки їхня свобода волі ще не була абсолютною, бо, як справедливо зауважував П. Біциллі, їх світогляд ще не був самостійним, а виражався в тісній єдності 3 Античністю [5, с. 29]. Важливим фактором несформованості ренесансної «особистості» стало й те, що увесь гуманістичний «пафос полягає в безпосередньому переживанні єдності Космосу, 
єдності Макрокосму й Мікрокосму. Виходячи 3 цього духовного досвіду, вони [гуманісти - уточ. наше], ставлячи проблему наближення людини до Бога, обожнювання людини, theosis'a, трактують ii в містичному дусі, підкреслюють значення безпосереднього почуття своєї божественності, властивого людині» [5, c. 42].

Висновки. Під час дослідження доходимо висновку, що в підсумку бурхливих соціокультурних, світоглядних та економічних трансформацій епохи Відродження розпочалося формування нового типу людини - незалежного від традиції та станових привілеїв господаря життя, який самовизначався тільки завдяки власній активності. Світоглядною передумовою формування нової соціальної програми стало переосмислення християнської догматики, що сприяло тлумаченню людини як носія божественних потенцій, які він має реалізувати в земному житті. Активна участь у громадянському й соціальному житті супроводжувалася інтенцією на звільнення людини від наперед визначених станових привілеїв, однак без надання конструктивної програми розвитку, що, своєю чергою, призвело до дезорієнтації людини в соціокультурному просторі.

Попри те що соціальна програма епохи Відродження заклала підвалини для формування нового образу людини, у цей час людина не перетворилася ні на автономного соціального суб’єкта, ні на особистість як 3 об’єктивних, так i суб' єктивних причин, а саме відсутність модерної демократії не надала можливості усвідомити природної рівності й унікальності всіх людей, унаслідок чого людина й надалі залишилася залежною від наперед визначених соціальних чинників. 3 другого боку, небувала активність людини поєднувалася 3 відсутністю конструктивної програми індивідуального й суспільного розвитку, що зумовило істотну дезорієнтацію людини у світі.

\section{Література:} C. $3-13$.

1. Аверинцев С. Два рождения европейского рационализма // Вопросы философии. 1989. № 3.

2. Apeопагит Дионисий. O божественных именах [Электронный pecypc]. URL : http : //www.hesychasm.ru/library/dar/tname.htm\#gl1

3. Баткин Л. М. Европейский человек наедине с собой. Очерки о культурно-исторических основаниях и пределах личного самосознания. М. : Российск. гос. гумат. ун-т, 2000. 1005 с. $272 \mathrm{c}$.

4. Баткин Л. М. Итальянское Возрождение в поисках индивидуальности. М.: Наука, 1989.

5. Бицилли П. М. Место Ренессанса в истории культуры. СПб. : Мифрил, 1996. 256 с.

6. Гарэн Э. Проблемы итальянского Возрождения. М. : Прогресс, 1986. 396 с.

7. Гегель Г. В.Ф. Лекции по истории философии. Книга третья [Электронный ресурс] // Электронная библиотека RoyalLib.com. URL :http://royallib.com/read/gegel_georg_vilgelm_fridrih/ lektsii_po_istorii_filosofii_kniga_tretya.html\#702996

8. Горфункель А. Х. Философия эпохи Возрождения. М. : Высш. школа, 1980. 368 с.

9. Гуковский М. А. Итальянское Возрождение. 2-е изд., испр. и доп. под ред. А. Немилова и А. Кантор-Гуковской. Л. : Издательство Ленинградского университета, 1990. 624 с.

10. Диктат папы [Электронный ресурс] // Словарь по христианству. URL : http ://religiocivilis.ru/ hristianstvo/christ-d/5308-diktat-papy.html 
11. Дойчик М. В. Філософія гідності доби Відродження // Міжнародна наукова конференція «Дні науки філософського факультету - 2010» : матеріали доповідей та виступів (Київ, 21-22 квітня 2010 р.), Ч. 1. Київ : Видавничо-поліграфічний центр «Київський університет», 2010. С. 23-26.

12. Кассирер Э. Избранное. Опыт о человеке. М. : Гардарика, 1998. 784 с.

13. Лалетин Д. Культурология [Электронный ресурс] // Библиотека Гумер. URL : http ://www.gumer.info/bibliotek_Buks/Culture/lalet/08.php

14. Лосев А. Эстетика Возрождения [Электронный ресурc]. URL: http://www.psylib.org.ua/ books/lose010/index.htm

15. Петрарка Ф. Лирика. Автобиографическая проза. М. : Правда, 1989. 480 с.

16. Пико делла Мирандола Дж. Речь о достоинстве человека [Электронный ресурс]. URL : http://psylib.org.ua/books/_pikodel.htm

17. Понтано Дж. Государь // Сочинения итальянских гуманистов эпохи Возрождения (XV век). М. : Издательство Московского университета, 1985. С. 290-308.

18. Рассел Б. История западной философии и ее связи с политическими и социальными условиями от Античности до наших дней [Электронный ресурc] URL : http://www.psylib.org.ua/books/rassb01/index.htm

19. Федик О. В., Гоян I. М. Концепт особистість як релікт модерної доби // Гуманітарний часопис. 2017, № 3/4. С. 6-15.

20. Хёйзинга Й. Осень Средневековья. СПб. : Изд-во Ивана Лимбаха, 2011. 768 с.

21. Storozhuk S., Hoyan I. Gender equality in the context of social relations // Cherkasy University Bulletin: Philosophy. 2018. №. 1. C. 3-16.

\section{Ihor Hoian, Svitlana Storozhuk, Oksana Fedyk}

\section{SOCIAL PROGRAM OF RENAISSANCE HUMANISM}

The radical socio-cultural transformations that take place around the world have led to a depreciation of those social standards that ensure the welfare of an industrial society, leading to the emergence of a new social program. The latter should become the conceptual basis of modern pedagogical strategies, since the primary responsibility for providing man with the knowledge and competences necessary in the new socio-cultural conditions is put on them. Meanwhile, in today's Ukrainian society, the reform of pedagogical strategies, as well as socio-cultural transformations, is perceived extremely ambiguously. According to media reports, a significant part of society is very concerned about the innovations that are taking place in the field of education, seeing them at risk of reducing education, which will necessitate an increase in social inequality and, accordingly, injustice and discrimination.

Awareness of the irreversibility of the changes that take place in the modern society, and with it, the increase in the level of tolerance to changes, is possible only if in the public consciousness there will be a clear understanding of the historical nature of those concepts and social programs that determine the life of each particular person and the society as a whole. This, in its turn, actualizes the rethinking of those social programs that determined the life of society in different historical periods. Far from the last place in the context of such research belongs to the social program of the Renaissance, because, on the one hand, it is from this time that researchers have usually deduced the origins of the present, and on the other hand, this era, as well as our present, is marked by significant sociocultural and 
ideological transformations, and therefore understanding the processes that initiated the Renaissance can contribute to a better understanding of the changes in our days.

Understanding the basic ideas of Renaissance humanism has repeatedly become the subject of scientific research by various researchers who have tried to form a general image and aspiration of thinkers of this age. In this context, it is appropriate to mention the works by S. Averintsev, L. Batkin, P. Bicilli, O. Horfunkel, I. Hoian, M. Hukovskyi, M. Doichyk, E. Cassirer, O. Losev, S. Storozhuk, J. Huizinga, O. Fedyk and other researchers who have enriched the modern vision of the achievements of this historical and philosophical period in the theoretical and methodological plan.

The extraordinary attention of Ukrainian and foreign researchers to the intellectual achievements of the Renaissance period would seem to be accompanied by a lack of works, which reveals the peculiarity of the social program initiated by humanists. In between, in our opinion, it is the latter that makes it possible to understand the role, place and purpose of a person in the world. On the other hand, this approach makes it possible to realize the value of this program from the perspective of the present. After all, as a result of the turbulent socio-cultural, ideological and economic transformations of the Renaissance, the formation of a new type of man - the owner of a life independent of tradition and class which is selfdetermined only through his own activity. A world-view precondition for the formation of a new social program was a rethinking of Christian dogma, which contributed to the interpretation of man as the bearer of divine potentials, which he must realize in earthly life. Active participation in civil and social life was accompanied by the intention to liberate people from pre-determined classes of privileges, but without a constructive program of human development that, in its turn, has led to a person's disorientation in the sociocultural space.

Despite the fact that the social program of the Renaissance laid the foundations for the formation of a new image of man, at that time man did not turn into an autonomous social subject, nor to a person, both from objective and subjective reasons namely: the lack of modern democracy did not make it possible to realize the natural equality and uniqueness of all people, as a result of which man remained dependent on predetermined social factors. On the other hand, the unprecedented activity of the man of the Renaissance was combined with the lack of a constructive program of individual and social development, which has led to a significant disorientation of man in the world. In other words, activity that does not provide for a clearly defined goal should not be seen as a positive sociocultural phenomenon.

Keywords: man, social program, socio-cultural changes, Renaissance humanism, personality, anthropocentrism. 


\section{Ігор Гоян, Світлана Сторожук, Оксана Федюк}

\section{СОЦІАЛЬНА ПРОГРАМА РЕНЕСАНСНОГО ГУМАНІЗМУ}

Докорінні соціокультурні трансформації, що відбуваються у всьому світі, призвели до знецінення тих соціальних стандартів, які забезпечували добробут індустріального суспільства, зумовивши постання нової соціальної програми. Остання має стати концептуальним підгрунтям сучасних педагогічних стратегій, адже саме на них покладається головна відповідальність за забезпечення людини необхідними в нових соціокультурних умовах знаннями та компетенціями. Поміж тим у сучасному українському суспільстві реформування педагогічних стратегій, так само як і соціокультурні трансформації, сприймаються надзвичайно неоднозначно. Вагома частина суспільства, як свідчать 3МI, дуже занепокоєна новаціями, що відбуваються у сфері освіти, убачаючи в них загрозу зниження рівня освіти, яке 3 необхідністю призведе до зростання соціальної нерівності й, відповідно, несправедливості та дискримінації.

Усвідомлення незворотності тих змін, які відбуваються в сучасному соціумі, а 3 ним і зростання рівня толерантності до змін можливі тільки в тому випадку, коли в суспільній свідомості 3'явиться чітке усвідомлення історичного характеру тих концептів і соціальних програм, які визначають життя кожної конкретної людини й суспільства загалом. Інакше кажучи, для того щоб ми могли зрозуміти якість і напрям тих реформ, що відбуваються в сучасній Україні та світі загалом, ми повинні усвідомити витоки й мету тих педагогічних і світоглядних стратегій, якими ми користуємось у власному житті. Це, своєю чергою, актуалізує переосмислення тих соціальних програм, які визначали життя суспільства в різні історичні періоди. Далеко не останнє місце в контексті такого дослідження належить соціальній програмі епохи Відродження, адже, $з$ одного боку, саме з цього часу дослідники зазвичай виводять витоки сучасності, а з другого боку, ця епоха, так само як і наша сучасність, позначена істотними соціокультурними й світоглядними трансформаціями, а тому осмислення тих процесів, які започаткував Ренесанс, може сприяти більш глибокому усвідомленню змін сьогодення.

Слід зазначити, що осмислення базових ідей ренесансного гуманізму вже неодноразово ставало предметом наукових розвідок різних дослідників, які намагалися сформувати загальний образ і прагнення мислителів цієї доби. У цьому контексті доречно згадати роботи С. Авєринцева, Л. Баткіна, П. Біциллі, О. Горфункеля, І. Гояна, М. Гуковського, М. Дойчика, Е. Кассірера, О. Лосєва, С. Сторожук, Й. Гейзинги, О.Федик та ін. дослідників, які в теоретикометодологічному плані збагатили сучасне бачення здобутків цього історикофілософського періоду.

Надзвичайно пильна, здавалося б, увага українських і зарубіжних дослідників до інтелектуальних здобутків доби Відродження супроводжується відсутністю праць, де розкривається своєрідність започаткованої гуманістами соціальної програми. Поміж тим, на наш погляд, саме остання надає можливість зрозуміти роль, місце й 
призначення людини у світі. 3 другого боку, такий підхід надає можливість усвідомити цінність цієї програми з перспективи сьогодення.

Під час дослідження доходимо висновку, що в підсумку бурхливих соціокультурних, світоглядних та економічних трансформацій епохи Відродження розпочалося формування нового типу людини - незалежного від традиції та станових привілеїв господаря життя, який самовизначався тільки завдяки власній активності. Світоглядною передумовою формування нової соціальної програми стало переосмислення християнської догматики, що сприяло тлумаченню людини як носія божественних потенцій, які вона має реалізувати в земному житті. Активна участь у громадянському й соціальному житті супроводжувалася інтенцією на звільнення людини від наперед визначених станових привілеїв, однак без надання конструктивної програми розвитку людини, що, своєю чергою, призвело до дезорієнтації людини в соціокультурному просторі.

Попри те що соціальна програма епохи Відродження заклала підвалини для формування нового образу людини, у цей час людина не перетворилася ні на автономного соціального суб'єкта, ні на особистість як 3 об'єктивних, так i суб'єктивних причин, а саме відсутність модерної демократії не надала можливості усвідомити природної рівності й унікальності всіх людей, унаслідок чого людина й надалі залишилася залежною від наперед визначених соціальних чинників. 3 другого боку, небувала активність людини поєднувалася 3 відсутністю конструктивної програми індивідуального й суспільного розвитку, що зумовило істотну дезорієнтацію людини у світі.

Ключові слова: людина, соціальна програма, соціокультурні зміни, ренесансний гуманізм, особистість, антропоцентризм.

Ihor Hoian, Professor of the Department of Philosophy, Sociology and Religious Studies Vasyl Stefanyk Pre-Carpathian National University.

Гоян Ігор Миколайович - доктор філософських наук, професор, професор кафедри філософії, соціології та релігієзнавства Прикарпатського національного університету імені Василя Стефаника, Івано-Франківськ, Україна.

e-mail: ivigoian@gmail.com

ORCID: 0000-0003-2548-0488

Svitlana Storozhuk, Professor of the Department of Philosophy National University of Life and Environmental Sciences of Ukraine.

Сторожук Світлана Володимирівна - доктор філософських наук, професор, професор кафедри філософії Національного університету біоресурсів i природокористування України, Київ, Україна.

e-mail: sveta0101@ukr.net

ORCID: 0000-0002-7947-6268

ResearcherID: E-1436-2016 
Oksana Fedyk, Associate Professor of Department of General and Clinical Psychology Vasyl Stefanyk Pre-Carpathian National University.

Федик Оксана Василівна - кандидат психологічних наук, доцент, доцент кафедри загальної та клінічної психології Прикарпатського національного університету імені Василя Стефаника, Івано-Франківськ, Україна.

e-mail: oksfedyk@ukr.net

ORCID: 0000-0002-9029-2611

Надійшла до редакції 07.08.2018. Розглянута на редколегії 17.09.2018.

\section{Рецензенти:}

Доктор філософських наук, завідувач кафедри філософії Національного аерокосмічного університету ім. М.С. Жуковського «XАI» Чернієнко В.О.

Доктор філософських наук, професор, декан гуманітарного факультету Національного аерокосмічного університету ім. М.С. Жуковського «ХАI» Копилов В.О. 